\title{
APPLICATION OF ARTIFICIAL NEURAL NETWORKS AND PARTICLE SWARM OPTIMIZATION FOR TIMBER EXTRACTION WITH CABLE CRANE
}

\author{
ÇALIŞKAN, E. \\ Department of Forest Engineering, Faculty of Forestry, Karadeniz Technical University \\ 61080 Trabzon, Turkey \\ (e-mail: caliskan@ktu.edu.tr) \\ (Received $13^{\text {th }}$ Nov 2018; accepted $11^{\text {th }}$ Jan 2019)
}

\begin{abstract}
The fact that forest areas in Turkey and the world are located at high and steep mountainous areas makes it more difficult to extraction the wood raw material. Therefore, the retreat of forest areas to mountainous areas has brought cable crane to the forefront. Thus, it has become possible to solve complex problems by way of artificial intelligence techniques. The purpose of this study was to determine the impact of factors related with timber extraction via URUSMIII cable crane on total time via Artificial Neural Network (ANN), Particle Swarm Optimization (PSO) and Multiple Regression Analysis (MRA). The data were obtained from oriental spruce timbers which were acquired from spruce stands in the Artvin Forest Directorate, located at NE Turkey. The factors with impact on total time (ground slope, line slope, lateral pull, number of logs, diameter of logs, length of logs, log volume, yarding distance) were measured along with the total time. Determination coefficient $(\mathrm{R})$ and the expressions that indicate error variance (MSE, RMSE and MAE) were taken into consideration for determining the model with the best results. PSO model was determined as the best structure $(\mathrm{R}=0.85 \mathrm{MSE}=0.0143$, $\mathrm{RMSE}=0.1194$, MAE $=0.0839$ ): in this study according to the obtained results. The results indicate that PSO had the best performance in the study followed by ANN and finally MRA with the lowest performance. The PSO model can be used for similar conditions on the planning of forest operation, the control of applications and the determination of unit of price for forest workers.
\end{abstract}

Keywords: forest operations, timber extraction, total time, artificial neural networks, particle swarm optimization, multiple regression analysis

\section{Introduction}

The need for timber continues to increase in Turkey every day; however forest areas continue to decrease rapidly. The transport stage is quite difficult, expensive and timeconsuming in forest management. It is an important issue that the product is extracted with the minimum damage to itself and the environment as well as with minimum loss of quality.

Cable crane systems are used for extraction purposes in many mountainous regions in the world. Since majority of the forests in countries such as Austria, Czech Republic, Japan, Norway and Scotland are located in mountainous areas, cable-crane systems are frequently used for extraction purposes (Russell and Mortimer, 2005; Huber and Stampfer, 2015; Proto and Zimbalatti, 2015)

As is known, forest cable-crane systems are manufactured in whole and are used for carrying heavy forest assets from the air over distances of 300-2000 m. According to yarding distance, these are called as short $(<300 \mathrm{~m})$, middle $(300-800 \mathrm{~m})$ and long $(800$ $<$ ) distance skylines (Acar et al., 2005).

URUSMIII cable crane was started to be used in our country during the late 1970s. Although it is not very widespread throughout the country, it is used extensively for timber extraction in the Artvin region (Acar and Şentürk, 2000). 
Cable cranes are quite different in comparison with other extraction methods. The volume is limited for manual extraction. Sliding is one-directional and can be carried out in case the incline is high. Animal-powered extraction cannot be performed from the top to the bottom in steep areas. Whereas for tractor extraction there are various disadvantages such as the issue that transportation cannot be made from the top to the bottom as well as short cable length.

Artificial Neural Networks (ANN) are used as a popular method by many different researchers in different engineering applications. ANN is a structure that based on the learning model of the human brain which contains neurons and is comprised of different layers by combining these neurons using different weights (Haykin, 1999). ANN is a very strong method especially for data modelling when regression coefficients are low (Esteban et al., 2009).

Heuristic optimization is used recently in algorithms in addition to artificial neural networks for improving the success and/or speed of artificial neural networks (Bağış and Çetin, 2009; Liu et al., 2008; Özbeyaz, 2010). Particle Swarm Optimization (PSO) which is one of the heuristic methods has been used successfully in many areas due to reasons such as the ease with which it can be implemented, the low number of parameters that need to be adjusted and the fact that it operates with real numbers. One of these is the training of artificial neural networks (Tamer and Karakuzu, 2006; Delice, 2008; Hema et al., 2008; Gu et al., 2009).

Various studies have been carried out on timber extraction operations during which time studies have been carried out for cable crane URUSMIII (Aykut et al., 1997; Çağlar, 2002; Baldini and Pollini, 1998; Heinrich, 1998; Trzesnowski, 1998; Ledoux and Huyler, 2000; Rieger, 2001; Krpan et al., 2001; Acar et al., 2005; Öztürk and Demir, 2007; Zimbalatti et al., 2009; Zimbalatti and Proto, 2010; Çalışkan, 2015).

The use of Artificial Neural Networks (ANN) and Particle Swarm Optimization (PSO) in timber extraction is at a starting stage in Turkey. Hence, there are no studies in literature which compare the performance of ANN and PSO with other models.

The purpose of this study was to examine the impact of factors related with the interaction of timber extraction with URUSMII cable crane on total time via ANN, PSO and MRA. The data were obtained from oriental spruce timbers from spruce stands in Artvin Forest Directorate, in NE Turkey.

\section{Materials and methods}

\section{Study area}

This study was carried out in the Ardanuç forest planning unit covering an area of approximately 76817.0 ha of forest with the growing stock 5.9 million $\mathrm{m}^{3}$ in the Artvin province in the northeastern Black Sea region of Turkey. The area was located between $41^{\circ} 12^{\prime}$ '34" North, and $41^{\circ} 48^{\prime}$ '55" East. Dominant tree species used for production purposes are natural oriental spruce (Picea orientalis Link.), and nordmann fir (Abies nordmanniana Stew) and oriental beech (Fagus orientalis Lipsky). The climate in Artvin is mild with humid summers. Annual precipitation and temperature averages approximately $700 \mathrm{~mm}$ and $13{ }^{\circ} \mathrm{C}$, respectively (Akman, 1990). Felling and delimbing operations were used to be carried out via chainsaws. Cable crane Urus (MIII) is mostly represented as off-road machines and have been widely used (Fig. 1). Urus MIII cable crane is generally used in uphill yarding operations, ranging from 500 to $600 \mathrm{~m}$ and combining with Mercedes Benz Unimog U1500 truck. Four workers are employed in 
operating the cable crane. The set up duration of cable crane is between 10 and $16 \mathrm{~h}$ and pull up duration is between 4 and $8 \mathrm{~h}$ depends on terrain conditions. The number of safety ropes ranges between 2 and 4 . The basic characteristics of the URUSMIII were given in (Çağlar et al., 2007; Öztürk and Şentürk, 2016).
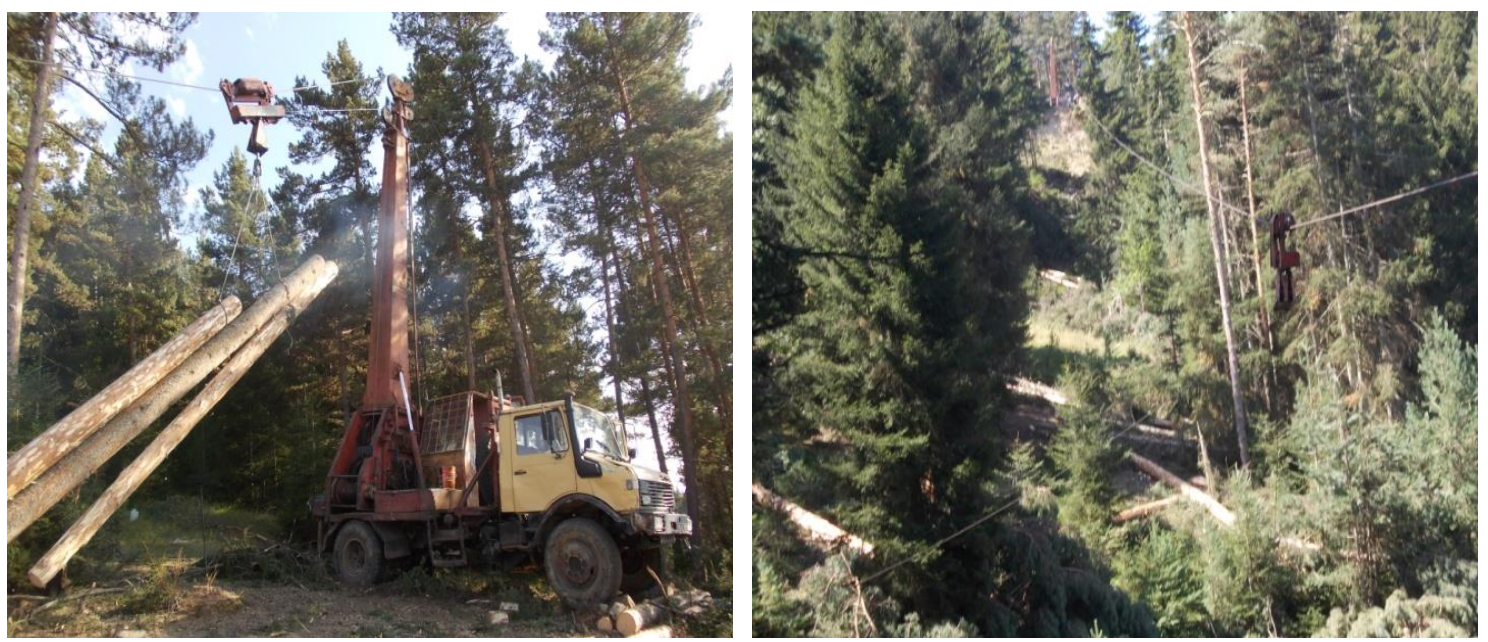

Figure 1. Urus MIII cable crane

\section{Field data collection}

Timber extraction was carried out using cable crane. Measured data for the timber operations have been recorded in study forms. Time values for each stage have been measured as 1/100 min (PM) using a chronometer, the amount of work done has been determined in units of $\mathrm{m}^{3}$, factors that affect the work done (ground slope, line slope, lateral pull, number of logs, diameter of logs, length of logs, log volume, yarding distance) have also been recorded in the study form. No intervention was made on the workers regarding issues such as starting and stopping of work, breaks, pauses, dealing with other operations.

Variables that were considered to have an impact on the work time for skidder timber extraction operations have been evaluated as $X_{i i}\left(X_{11}-X_{18}\right)$ and expressed in numerical values. These variables have been briefly explained in Table 1.

Repetition time measurement method was used for time measurements and the work phases, total turn time and waiting times were determined using a digital chronometer. The measured time values were obtained for a two person working group in units of $1 / 100 \mathrm{~min}$. Work phases and related time values have been expressed as $Y_{i i}\left(Y_{11}-Y_{19}\right)$ for cable crane timber extraction operations and related time values have been briefly explained in Table 1.

Measurements and observations were carried out for timber extraction operations for spruce trees using cable crane (Hauling back of empty carriage $\left(Y_{11}\right)$, Descending of bundle hook $\left(Y_{12}\right)$, Pulling of hook to $\operatorname{logs}\left(Y_{13}\right)$, Pulling of loaded hook to carriage $\left(Y_{14}\right)$, Moving of loaded carriage to landing site $\left(Y_{15}\right)$, Descending of loaded hook to ground $\left(Y_{16}\right)$, Unhooking of loads $\left(Y_{17}\right)$, Pulling backwards of empty carriage $\left(Y_{18}\right)$, Nonworking time (which covers spare and delay time of workers $\left(Y_{19}\right)$, Total activity time $\left(y_{f a}\right)$.

Total activity time (Eq. 1): 


$$
y_{f a}=y_{11}+y_{12}+y_{13}+y_{14}+y_{15}+y_{16}+y_{17}+y_{18}+y_{19}
$$

The ANN-PSO models were generated using Matlab software. Statistical analyses were carried out via "SPSS 21.0" software.

\section{Artificial neural network (ANN)}

Artificial neural networks are mathematical models inspired by the structure and behavior of the human brain (Olden et al., 2008). The ANN network includes three main layers: input, hidden and output. These layers are used for data input, data transmission and data output respectively. The hidden layer function is used to transfer the results to the output layer (Fausett, 1994; Haykin, 1994). The output of each neuron can be written as (Eq. 2):

$$
y_{i}=f\left(\sum w_{i j} x_{i}\right)
$$

where $y i$ represents the input that a single node $\mathrm{j}$ receives. The function $\mathrm{f}$ can be a simple threshold, sigmoid or hyperbolic tangent function. The weights between the nodes $\mathrm{i}$ and $\mathrm{j}$ are denoted as $w_{i j}$ : $x_{i}$ represents the output from node $\mathrm{i}$.

Whereas the input layer in this study was comprised of 8 neurons as ground slope, line slope, lateral pull, number of logs, diameter of logs, length of logs, log volume and yarding distance; there was only 1 neuron of Total activity time $\left(y_{f a}\right)$ in the output layer. The number of neurons in the hidden layer varies according to the characteristic of the problem.

Back propagation algorithm (BPA) is used for training ANN networks in this study since it is easy to understand and prove mathematically. The back propagation artificial neural network models have already been described and are used widely (Rumelhart et al., 1986; Fausett, 1994; Haykin, 1994; Özçelik et al., 2010).

The hyperbolic tangent sigmoid (tansig) transfer function presented by the following equation was used between the input and hidden layers in the model in this study (Fausett, 1994). A linear (pureline) transfer function was used between the hidden and output layers.

NET: Weighted sum (Eq. 3)

$$
f\left(N E T_{i}\right)=\frac{1}{1+e^{-N E T_{i}}}, f\left(N E T_{i}\right)=N E T_{i}
$$

BPA uses two parameters that control the speed at which training takes place. The learning coefficient determines the amount of change in the weights. It was observed that values ranging between 0.2 and 0.4 are generally used and that the value of 0.6 yields the most successful results (Öztemel, 2003). The momentum coefficient has an impact on training performance. It was observed that selecting a value ranging between 0.6 and 0.8 would be best (Öztemel, 2003).

\section{Particle swarm optimization (PSO)}

Particle Swarm Optimization (PSO) was first developed by Kennedy and Eberhart (1995) inspired by the behaviors of bird swarms when trying to find food. The 
population is defined as swarm in this algorithm, whereas each individual is defined as particle. These particles are accepted to be flowing in multi-dimensional space. PSO can be applied successfully in many areas such as artificial neural network training (Zhao et al., 2005; Awad, 2006).

PSO is started with a group of random values (particle swarm) and the optimum solution is tried to be determined by way of iterations. Particle positions are updated according to the best two values in each iteration. The first value includes the coordinates that provides the best solution for that particle until that point. This value is defined as "pbest" and should be stored in memory. Whereas the other best value includes the coordinates that provides the best solution for all particles in that population until that moment. This is the global best value and is denoted as "gbest". For example, let us assume that there are $\mathrm{n}$ particles comprised of D parameters.

Every particle has its own position, velocity and best solution. The PSO method can be presented as follows (Elbeltagi et al., 2005; Al_Janabi et al., 2018):

The swarm position in a $\mathrm{D}$ space of the $i$ th particle can be presented by (Eq. 4):

$$
X_{i}=\left(X_{i 1}, X_{i 2}, X_{i 3}, \ldots, X_{i D}\right), \quad i=1,2,3, . ., N
$$

Whereas velocity of each particle can be represented as (Eq. 5):

$$
V_{i}=\left(V_{i 1}, V_{i 2}, V_{i 3}, \ldots, V_{i D}\right), \quad i=1,2,3, . ., N
$$

Each particle maintains a memory of its previous best position. The best swarm position is given by $(E q .6)$ :

$$
\text { pbest }_{i}=\left(\text { pbest }_{i 1}, \text { pbest }_{i 2}, \text { pbest }_{i 3}, \ldots, \text { pbest }_{i d}\right), \quad i=1,2,3, . ., N
$$

gbest is unique for all particles in each iteration (Eq. 7):

$$
\text { gbest }_{i}=\left(\text { gbest }_{i 1}, \text { gbest }_{i 2}, \text { gbest }_{i 3}, \ldots, \text { gbest }_{i d}\right), \quad i=1,2,3, . ., N
$$

A particle velocity should be updated and the following equation can be used (Eqs. 8-9):

$$
\begin{gathered}
V_{i}^{k+1}=V_{i}^{k}+c_{1} r_{1}^{k} \cdot\left(\text { pbest }_{i}^{k}-x_{i}^{k}\right)+c_{2} \text { rand }_{2} \cdot\left(\text { gbest }_{i}^{k}-x_{i}^{k}\right) \\
\text { Fitness }=\sum_{i}\left(Y_{i}-X_{i} V\right)^{2}
\end{gathered}
$$

where the parameters of $\mathrm{c}_{1}, \mathrm{c}_{2}$ are constants and $\mathrm{r}_{1}, \mathrm{r}_{2}$ are random numbers ranging between $0-1$. pbest $t_{i}$ is the best local solution of the $i$ th particle for the iteration number up to the $i$ th iteration. The best global solution of all particles is gbest. The "inertia weight" w controls the effect of the previous velocity of the particle on the current one. If the value of $\mathrm{w}$ is greater than 1, it means that the particle favored searching over exploitation; whereas a $\mathrm{w}$ value of less than 1 is an indication that the particle gave more importance to the current best positions (Al_Janabi et al., 2018). 
Network architecture, training rate and momentum factor have been determined in our study after examining different combinations. Several different ANN models were developed and tested in order to determine the optimal number of neurons in the hidden layer by trial and error estimates. A single hidden layer was used to significantly reduce the computational time. The general structure of ANN is shown in Figure 2.

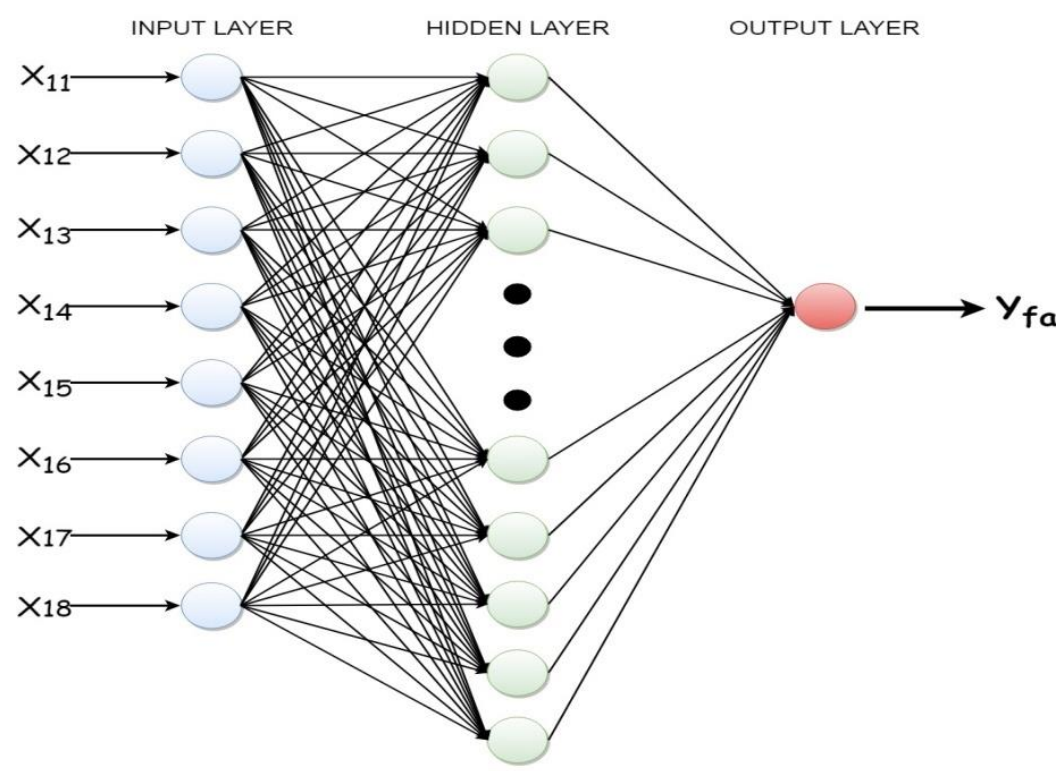

Figure 2. Schematic diagram of ANN model

\section{Multiple regression analysis (MRA)}

Regression is one of the methods used for testing whether there is a relationship between two or more variables and to express the relationship between the variables by way of linear or curvilinear equations (Öztürkcan, 2009). Regression analysis using more than one independent variable is called multiple regression analysis.

The general structure of the equation in cases when there is more than one independent variable (such as $\left.X_{1}, X_{2}, X_{3}, \ldots\right)(E q .10)$ :

$$
Y=\beta_{0}+\beta_{1} x_{1}+\beta_{2} x_{2}+\beta_{3} x_{3}+\ldots+\beta_{n} x_{n} \pm \varepsilon
$$

where Y: dependent variable, $X i$ : independent variable $(i=1,2,3, . ., N) \quad \beta_{i}$ : regression parameters $(i=1,2,3, \ldots, N), \varepsilon$ : random error and $n$ : number of unknown parameters.

In this study, ground slope, line slope, lateral pull, number of logs, diameter of logs, length of logs, log volume, yarding distance are selected as the independent variables and total time is selected as the dependent variable.

Statistical calculations on variables that are independent from $\left(x_{i i}\right)$ and dependent on $\left(y_{i i}\right)$ measurement results have been carried out as:

- Calculation of the average and deviations,

- Examination of the variables that are effective on the actual time spent for each work phase or the unit time value, 
- Examination of the relations between variables,

- And determination of the impact of independent variables on the total time spent for work phases

\section{Model evaluation criteria}

In this study, the performance of different predictive models is evaluated by using statistical measures including the; Corrected determination coefficient (R), Mean Squared Error (MSE), Root Mean Square Error (RMSE) and mean absolute error (MAE) were used as criteria for comparing ANN, PSO and MRA. Accordingly, high R and low MSE, RMSE and MAE values indicate the best model. MAE and MSE values were close to 0 and the $\mathrm{R}$ value was close to 1 , thereby indicating that the predicted value strongly converges to the right (Hocking, 1976; Law, 1999; Cho, 2003; Arrkan, 2014).

a) The correlation coefficient (R) (Eq. 11):

$$
R=\frac{\sum\left(X_{i}-\bar{X}\right)\left(Y_{i}-\bar{Y}\right)}{\sqrt{\sum\left(X_{i}-\bar{X}\right)^{2}\left(Y_{i}-\bar{Y}\right)^{2}}}
$$

b) Mean squared error (MSE) (Eq. 12):

$$
M S E=\frac{1}{n} \sum_{i=1}^{n}\left(y_{i}-\hat{y}_{i}\right)^{2}
$$

c) Root mean square error (RMSE) (Eq. 13):

$$
R M S E=\sqrt{\frac{\sum_{i=1}^{n}\left(x_{i}-y_{i}\right)^{2}}{n}}
$$

d) Mean absolute error (MAE) (Eq. 14):

$$
M A E=\frac{\sum_{i=1}^{n}\left(x_{i}-y_{i}\right)}{n}
$$

where $X_{i}$ and $Y_{i}$ are the observed and predicted data, respectively; $\bar{X}$ and $\bar{Y}$ are the mean of the observed and predicted and $n$ the number of observations in the dataset.

\section{Results and discussion}

The arithmetic average, standard deviation, max and min values for the actual time values measured in units of $1 / 100 \mathrm{~min}$ as the variables of observed values regarding the work phases via cable crane have been calculated and presented in Table 1. 
Single input variance analysis was used to examine whether the impact of the correlation matrix indicating the relationship between the variables and $x_{i i}$ groups on the values of $y_{i i}$ was statistically significant or not.

Table 1. Work phases and their descriptive statistics

\begin{tabular}{c|c|c|c|c|c|c|c|c|c}
\hline Work phases & Average & Std. dev. & Min. & Max. & Work phases & Average & Std. dev. & Min. & Max. \\
\hline $\begin{array}{c}y_{11}: \text { Hauling back of } \\
\text { empty carriage }\end{array}$ & 33.00 & 17.76 & 15.00 & 111.0 & $\begin{array}{c}y_{f a}: \text { Total activity } \\
\text { time }\end{array}$ & 619.0 & 253.1 & 275.0 & 1422 \\
\hline $\begin{array}{c}y_{11}: \text { Descending of } \\
\text { bundle hook }\end{array}$ & 32.0 & 21.04 & 10.00 & 114.0 & $x_{11}$ : Ground slope & 70.33 & 1.69 & 68.00 & 73.00 \\
\hline $\begin{array}{c}y_{13}: \text { Pulling of hook to } \\
\text { logs }\end{array}$ & 167.0 & 107.2 & 31.00 & 500.0 & $x_{12}:$ Line slope & 51.97 & 0.23 & 51.00 & 52.00 \\
\hline $\begin{array}{c}y_{14}: \text { Pulling of loaded } \\
\text { hook to carriage }\end{array}$ & 69.22 & 71.15 & 60.00 & 499.0 & $\begin{array}{c}x_{13}: \text { Lateral pull } \\
\text { distance }\end{array}$ & 20.76 & 0.64 & 10.00 & 35.00 \\
\hline $\begin{array}{c}y_{15}: \text { Moving of loaded } \\
\text { carriage to landing site }\end{array}$ & 233.0 & 97.55 & 101.0 & 447.0 & $\begin{array}{c}x_{14}: \text { Yarding } \\
\text { distance }\end{array}$ & 140.92 & 61.72 & 70.00 & 250.00 \\
\hline $\begin{array}{c}y_{16}: \text { Descending of } \\
\text { loaded hook to ground }\end{array}$ & 10.00 & 3.52 & 4.00 & 230.0 & $\begin{array}{c}x_{15}: \text { Diameter of } \\
\text { logs }\end{array}$ & 33.76 & 8.78 & 22.00 & 61.00 \\
\hline $\begin{array}{c}y_{17}: \text { Unhooking of } \\
\text { loads }\end{array}$ & 29.65 & 23.79 & 5.00 & 218.0 & $\begin{array}{c}x_{16}: \text { Length of } \\
\text { logs }\end{array}$ & 5.24 & 1.05 & 3.00 & 8.00 \\
\hline $\begin{array}{c}y_{18}: \text { Pulling backwards } \\
\text { of empty carriage }\end{array}$ & 7.44 & 1.43 & 4.00 & 12.00 & $\begin{array}{c}x_{17}: \text { Number of } \\
\text { logs }\end{array}$ & 3.15 & 0.98 & 1.00 & 6.00 \\
\hline$y_{19}$ : Nonworking time & 36.00 & 43.90 & 8.00 & 314.4 & $x_{18}:$ Log volume & 1.49 & 0.69 & 0.57 & 3.65 \\
\hline
\end{tabular}

The data were first normalized (0-1) in this study and $70 \%$ and $30 \%$ of the complete data was used for training and testing respectively. Therefore, 27 testing and 64 training data sets were randomly selected from all land data. The training set adjusts the connection weights and the parameters of the model and the testing set evaluates the trained ANN performance and generalization power (Ghajar et al., 2012a, b).

A network with eight inputs, one hidden layer, and one output was selected in this study. The inputs were: ground slope $\left(\mathrm{x}_{11}\right)$, line slope $\left(\mathrm{x}_{12}\right)$, lateral pull distance $\left(\mathrm{x}_{13}\right)$, extraction distance $\left(\mathrm{x}_{14}\right)$, diameter of $\operatorname{logs}\left(\mathrm{x}_{15}\right)$, length of $\operatorname{logs}\left(\mathrm{x}_{16}\right)$, number of $\operatorname{logs}\left(\mathrm{x}_{17}\right)$, and $\log$ volume ( $\left.\mathrm{x}_{18}\right)$; while the output was Total activity time (Cable crane, yfa).

An 8 layer artificial neural network was established in this study and a backpropagation algorithm (BPA) was used as a learning algorithm. The hidden layer and the number of neurons in this layer were determined through trial and error. In this regard, one hidden layer with fifteen (15) neurons was included in the model. Neurons with numbers ranging from 1 to 30 were given to this layer in order to determine the number of neurons that would be included in the hidden layer and each model was tested 10 times to determine the best model for our study. The sigmoid transfer functions were used in input, hidden and output layers in the model. The most suitable model was identified as the model with a network structure of 8-15-1.

Each combination of learning rates and momentum factors were tested for different numbers of hidden neurons. The network was trained in variable epochs via ANN learning algorithm with a learning rate of 0.001 and a momentum coefficient of 0.2 . This was the best combination that conducts to the smaller values of R, MSE, RMSE and MAE in Table 2. Regression values for the data used in the training and testing of the ANN have been given in Figure 3. 

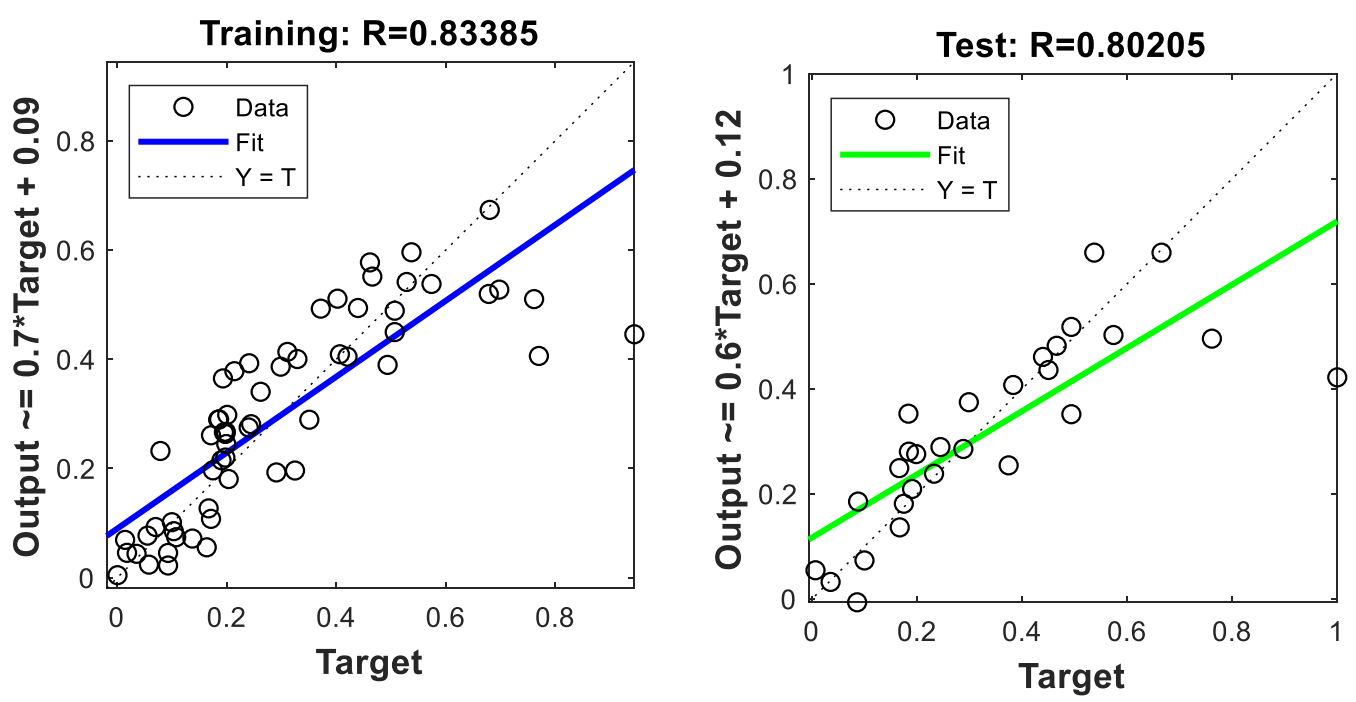

Figure 3. Training and test, distribution graphs for the ANN prediction model

Figure 3 shows the $\mathrm{R}$ values graph for the training and test stages of the studied model. The values determined were $R=0.8338$ for the learning stage and $R=0.8020$ for the test stage of the model. Figures 4 and 5 respectively show the graphs comparing the model predictions and observed values for the ANN model.

It can be observed from Figures 4 and 5 that the values of the total time during cable crane operations were generally predicted to be close to the observed value.

As mentioned, PSO was used as the artificial neural network algorithm in this study and MSE was applied as a fitness function. The objective of this algorithm is decreasing MSE. The number of data used for training and testing were 64 and 27, respectively.

ANN learning process was started by randomly generating the weights that hold the numerical value of the connections between the layers. These weights express the particle values for PSO. Whereas the number of connections between the layers represents the particle size. The network was setup for each particle and training samples were sent to the network in order. Total error (MSE) was calculated after all values were presented to the network and the obtained value was accepted as the fitness value. This fitness value is determined as the pbest value in the first step; whereas the best fitness value among the particles is determined as gbest. If the fitness value that is the error is not at an acceptable value, the particles are updated with pbest and gbest values. The network was re-established according to the new particle values, the values were resent to the network and fitness value calculation was carried out. These operations are carried out until the best fitness value (gbest) reaches the desired value (very close to 0 ) or until the maximum number of iterations.

Test process is started if the error is at an acceptable level. This time the network is setup according to the (gbest) particle values, test samples are sent to the input layer in order and the acquired values are provided as the sample output. The last acquired gbest value gives the classification performance of the network when no threshold is applied on the network output.

As a result of the experiments; the optimal parameters for ANN-PSO were determined as; number of hidden neurons $=18$, number of particles $=25$, number of iterations $=500,\left(c_{1}\right.$ and $c_{2}=2$ ). Particle numbers generally range from 20 to 40 (Tamer 
and Karakuzu, 2006). It was stated in the experiments conducted by the researchers on this algorithm that $\mathrm{c} 1=\mathrm{c} 2=2$ gave good results (Shi and Eberhart, 1998; Liping et al., 2005).

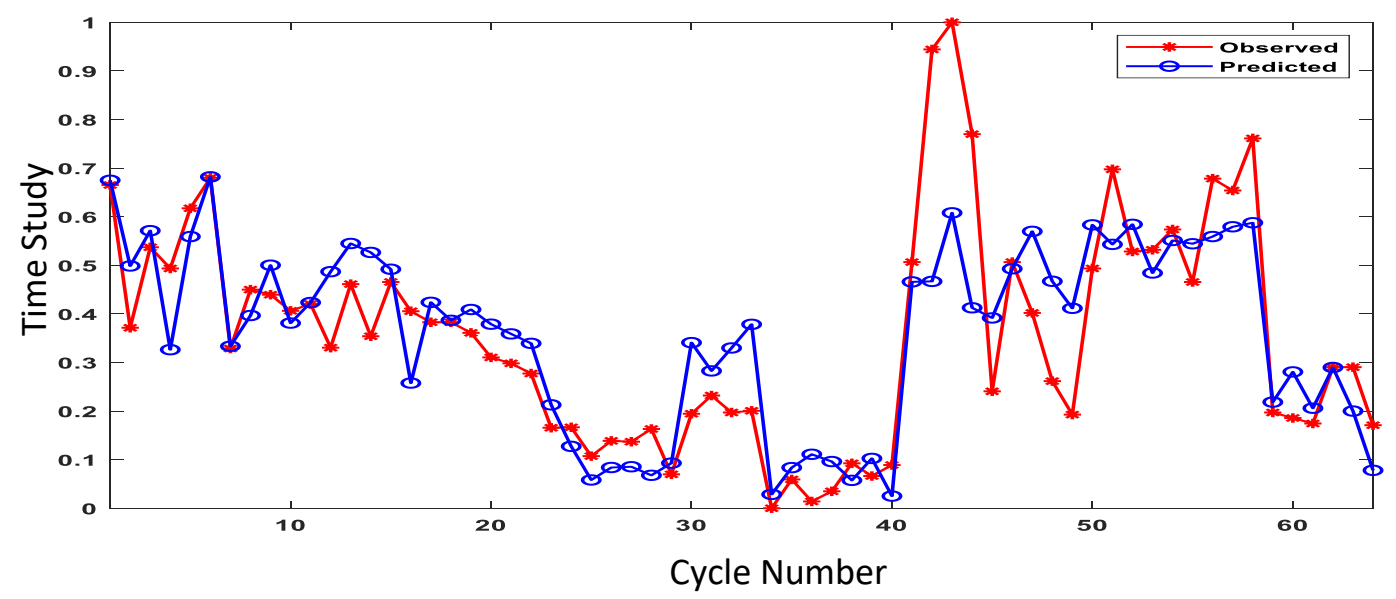

Figure 4. Comparison of predicted and observed values for training sets using ANN

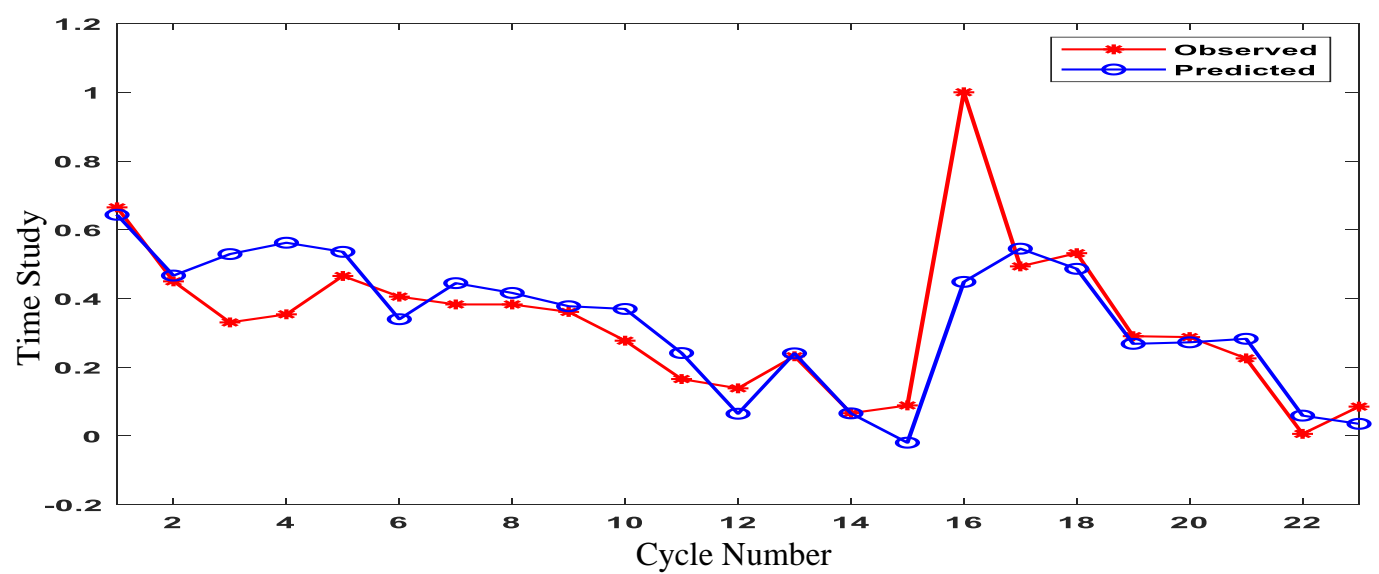

Figure 5. Comparison of predicted and observed values for test sets using ANN

This was the best combination that conducts to the smaller values of R, MSE, RMSE and MAE in Table 2. Figures 6 and 7 show the graphs in comparison with the model predictions and observed values for the PSO model.

It can be observed from Figures 6 and 7 that the values of the total time cable crane operations are generally predicted close to the observed value.

Alternative equalities have been generated via multiple regression analysis. Operations carried out for the timber extraction total activity time with cable crane $\left(\mathrm{y}_{\mathrm{fa}}\right)$ have been given in detail.

Regression equalities based on the $\left.y_{f a}=f\left(X_{11}, X_{12}, X_{13}, X_{14}, X_{15}, X_{16}, X_{17}\right), X_{18}\right)$ relationship have been given in Table 2. Consistency of the equation was tested using the coefficients obtained from the regression equation and test data. Graphs that compare the model predictions obtained from the MRA model and the observed values have been given in Figure 8. 
It can be observed from Figure 8 that the values of the total time during cable crane operations are generally predicted close to the observed value.

Table 2. Regression equalities for calculating the total activity time of timber extraction via cable crane

\begin{tabular}{c|c|c|c|c|c|c|c|c|c|c|c}
\hline Nu & Total time & $\boldsymbol{b}$ & $\boldsymbol{X}_{11}$ & $\boldsymbol{X}_{12}$ & $\boldsymbol{X}_{13}$ & $\boldsymbol{X}_{14}$ & $\boldsymbol{X}_{15}$ & $\boldsymbol{X}_{\boldsymbol{I b}}$ & $\boldsymbol{X}_{17}$ & $\boldsymbol{X}_{\boldsymbol{I s}}$ & $\mathbf{R}$-sq \\
\hline 1 & $y_{f a}$ & -6.14 & 0.19 & 0.39 & 0.13 & 0.02 & -0.01 & 0.14 & -1.5 & -0.21 & 0.699 \\
\hline 2 & $y_{f a}$ & -6.23 & 0.19 & 0.39 & 0.13 & 0.02 & & -0.14 & 0.16 & -0.22 & 0.698 \\
\hline 3 & $y_{f a}$ & 13.80 & 0.18 & & 0.13 & 0.22 & & 0.14 & 0.49 & -0.21 & 0.697 \\
\hline 4 & $y_{f a}$ & 11.62 & 0.16 & & 0.14 & 0.22 & & 0.19 & 0.27 & & 0.695 \\
\hline 5 & $y_{f a}$ & 10.66 & 0.15 & & 0.14 & 0.22 & & & 0.17 & & 0.690 \\
\hline 6 & $y_{f a}$ & 10.63 & 0.14 & & 0.13 & 0.22 & & & & & 0.685 \\
\hline 7 & $y_{f a}$ & -0.11 & & & 0.13 & 0.24 & & & & & 0.677 \\
\hline
\end{tabular}

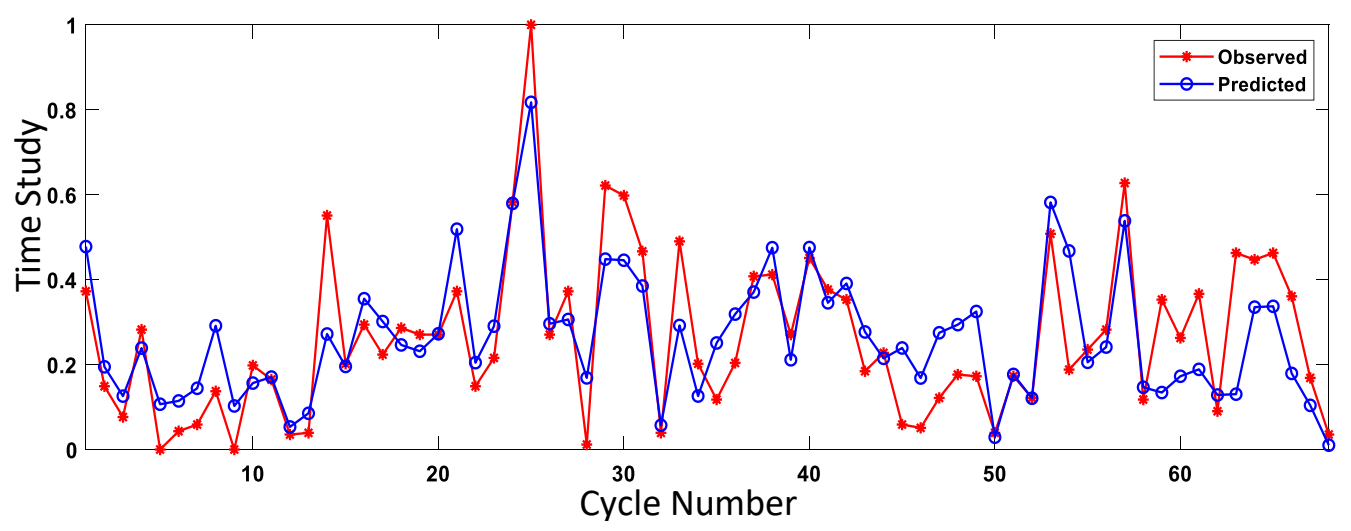

Figure 6. Comparison of predicted and observed values for training sets using PSO

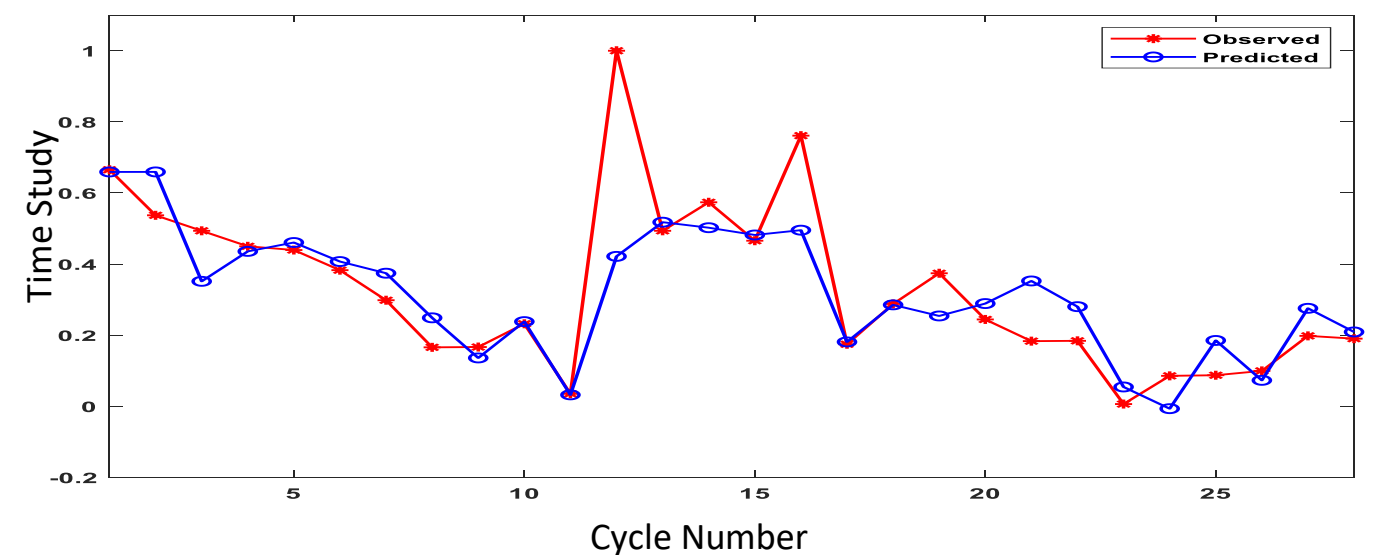

Figure 7. Comparison of predicted and observed values for test sets using PSO 


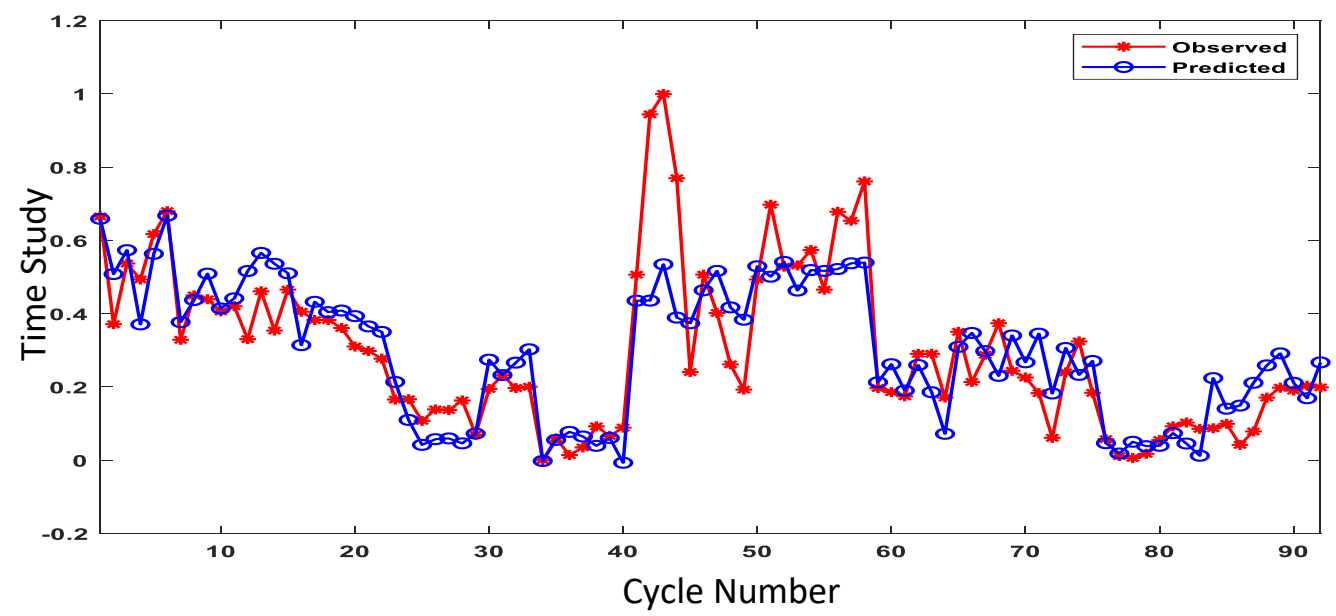

Figure 8. Comparison of predicted and observed values using MRA

The performances for predicting total activity time for cable crane are compared using three techniques as ANN, PSO and MRA. The values of performance measures are given in Table 3.

Table 3. A comparison of the ANN, PSO and MRA, models

\begin{tabular}{c|c|c|c|c}
\hline Model & R & MSE & RMSE & MAE \\
\hline PSO & 0.85 & 0.0143 & 0.1194 & 0.0839 \\
ANN & 0.83 & 0.0152 & 0.1232 & 0.0907 \\
MRA & 0.69 & 0.0194 & 0.1434 & 0.1186 \\
\hline
\end{tabular}

Values of R, MSE, RMSE and MAE were compared at the end of the study for determining the algorithm with the best performance. Based on the results obtained from this study, the PSO has been found to be better than the ANN and MRA models, because the PSO has a higher ability in global search than in ANN and MRA models.

ANN and PSO have been applied successfully in the field of forest modeling. Specifically, artificial neural network approach has been carried out for many objectives such as modeling individual tree survival probabilities (Guan and Gertner, 1995), diameter growth based climatic variables (Zhang et al., 2000); wildlife planning issues (Bettinger et al.,2002), forecasting wood demand (Güngör et al., 2004) tree volume (Diamantopoulou, 2005a; Diamantopoulou and Milios, 2010; Özçelik et al., 2008, 2010), tree stem diameters (Diamantopoulou, 2005b, 2006; Leite et al., 2011), predicting forest fire burn areas (Cortez and Morais, 2007), forest planning (Pukkala, 2009), tree felling times (Karaman and Çalışkan, 2009), tree heights (Özçelik et al., 2013), prediction of skidding time (Naghdi and Ghajar, 2012), trunk volume estimates ((Bayati and Najafi; 2013), predicted forest fire burn areas (Safi and Bouroumi, 2013), forest feature extraction ( $\mathrm{Li}$ et al., 2014), prediction of winching time (Bayati and Najafi; 2015), tree diameter increments (Ercanlı et al., 2016) and describing diameter distribution (Bolat et al., 2016), predicting forest fire (Al_Janabi et al., 2018). 


\section{Conclusion}

In this study, the impact of factors interacting during timber extraction via URUSMIII cable crane on total time was determined by using ANN, PSO and MRA. The data were obtained from oriental spruce timbers from spruce stands in Artvin Forest Directorate located at NE Turkey. In the study, $70 \%$ and $30 \%$ of the complete dataset were used for training and testing, respectively. Therefore, 27 testing and 64 training data sets were randomly selected from all land data.

Determination coefficient $(\mathrm{R})$ and the expressions that indicate error variance (MSE, RMSE and MAE) were taken into consideration for determining the model with the best results. The $\mathrm{R}$ values obtained in the study were determined to vary between 0.85 and 0.83 for PSO and ANN respectively and as 0.69 when MRA was used.

Based on the results obtained from this study, it was determined that the performance of PSO model was better compared to ANN and MRA. The study also indicates that PSO may be used efficiently in forestry operations.

Acknowledgements. The author wishes to thank student Mr. Kamil BILLGIN and employees of Ardanuç Forest Enterprise who contributed to this study. I also thank Dr. Yusuf Sevim for his support and contributions in Matlab. Moreover the author wishes to thank two anonymous reviewers for their useful comments and advice.

\section{REFERENCES}

[1] Acar, H. H., Şentürk, N. (2000): Dağlık Orman Alanlarındaki Üretim Çalışmalarında Mekanizasyon. - İstanbul Üniversitesi Orman Fakültesi Dergisi, Seri: B 46: 77-94 (in Turkish).

[2] Acar, H. H., Topalak, O., Eroglu, H. (2005): Forest skylines in Turkish forestry. - Meh. Sumar. 26(2) 137-140.

[3] Akman Y (1990): Climate and Bioclimate. - Palme Publication, Ankara.

[4] Al_Janabi, S., Al_Shourbaji, İ., Salman, M. A. (2018): Assessing the suitability of soft computing approaches for forest fires prediction. - Applied Computing and Informatics 14(2): 214-224.

[5] Aykut, T., Acar, H. H., Senturk, N. (1997): An investigation on comparing of Koller K 300, Urus M III and Gantner forest skylines used timber extraction on Artvin region. Review of the Faculty of Forestry, University of İstanbul, Serial A 47(2): 30-54.

[6] Arikan, K. V. S. (2014): A comparison of artificial neural networks and multiple linear regression models as in predictors of fabric weft defects. - Tekstil ve Konfeksiyon 24(3): 309-316.

[7] Awad, H. A. (2006): A novel particle swarm-based fuzzy control scheme. - IEEE International Conference on Fuzzy Systems, July 16-21, Canada.

[8] Bağış, A., Çetin, O. (2009): Doğrusal Olmayan Bir Sistemin Bulanık Kural Parametrelerinin PSO Algoritması İle Optimize Edilmesi. - Electronic Letters on Science \& Engineering 5(1) (in Turkish).

[9] Baldini, S., Pollini, C. (1998): Interaction between interaction of services: forestry and wood harvesting systems. - Proceedings of the Seminar on Environmentally Sound Forest Roads and Wood Transport. Sinaia, Romania, 17-22 June, 1996. FAO, Rome, pp 337-341.

[10] Bayati, H., Najafi, A. (2013): Performance comparison artificial neural networks with regression analysis in trees trunk volume estimation. - Journal of Forest and Wood Products, Iranian Journal of Natural Resources 66(2): 177-191. 
[11] Bayati, H., Najafi, A. (2015): Performance evaluation of artificial neural networks for modeling winching time of a Timber Jack 450 C. - Proceedings of the 48th FORMEC Symposium, Oct 4-8, Linz, Austria.

[12] Bettinger, P., Graetz, D., Boston, K., Sessions, J., Chung, W. (2002): Eight heuristic planning techniques applied to three increasingly difficult wildlife planning problems. Silva Fennica 36(2): 561-584.

[13] Bolat, F., Ercanll, İ. (2016): Using artificial neural network in describing diameter distribution in an even-aged forest. - International Forestry Symposium (IFS 2016) Proceedings, 07-10 December, Kastamonu, Turkey, pp. 536-541.

[14] Cortez, P., Morais, A. (2007): A data mining approach to predict forest fires using meteorological data. - Portuguese Conference on Artificial Intelligence, Guimares, Portugal, pp. 512-520.

[15] Cho, V. (2003): A comparison of three different approachs to tourist arrival forecasting. Tourism Management 24: 323-330.

[16] Çağlar, S. (2002): An investigation of the transport from compartment with cable cranes aspect of working productivity in Artvin Region. - Master Thesis, Kafkas University, Artvin (in Turkish).

[17] Çağlar, S., Acar, H. H., Çalışkan, E. (2007): An examination on machine extraction systems in turkish forestry. - Annals of Warsaw Agricultural University (SGGW), 6th Conference on Agricultural and Forest Engineering, 14-15 June 2007, Warsaw, Poland.

[18] Çaliskan, E. (2015): Timber extraction with a cable crane in Turkey. - Environmentally Friendly Agriculture and Forestry for Future Generations, XXXVI CIOSTA CIGR V Conference, 26-28 May, 2015, Saint Petersburg, Russian Federation.

[19] Delice, Y. (2008): Parçacık Sürü Optimizasyonu ile Yapay Sinir Ağlarından Sınıflandırma Kuralı Çıkarımı. - Erciyes Üniversitesi Sosyal Bilimler Enstitüsü, Kayseri.

[20] Diamantopoulou, M. J. (2005a). Artificial neural networks as an alternative tool in pine bark volume estimation. - Computers and Electronics in Agriculture 48: 235-244.

[21] Diamantopoulou, M. J. (2005b). Predicting fir trees stem diameters using Artificial Neural Network models. - Southern Forests: A Journal of Forestry Science 205: 39-44.

[22] Diamantopoulou, M. J., Milios, E. (2010): Modelling total volume of dominant pine-trees in reforestations via multivariate analysis and artificial neural network models. Biosystems Engineering 105: 306-315.

[23] Elbeltagi, E. Hegazy, T., Grierson, D. (2005): Comparison among five evolutionarybased optimizationalgorithms. - Advanced Eng. Informatics 19: 43-53.

[24] Ercanl, İ., Kahriman, A., Yavuz, H. (2016): predicting oriental spruce and scots pine tree diameter increments based on artificial neural network located in mixed oriental sprucescots pine stands at Trabzon and Giresun forest district. - International Forestry Symposium (IFS 2016) Proceedings, 07-10 December, Kastamonu, Turkey pp. 554-558.

[25] Esteban, L. G., Fernandez, F. G., de Palacios, P. (2009): MOE prediction in Abies pinsapo boiss. timber: application of an artificial neural network using non-destructive testing. - Computers and Structures 87: 1360-1365.

[26] Fausett, L. (1994): Fundamentals of Neural Networks Architectures. Algorithms and Applications. - Prentice Hall, Upper Saddle River, NJ.

[27] GDF (2017): Activities of 2013 Year Report (2017 Y1lı Faaliyet Raporu). - General Directorate of Forestry, Ankara.

[28] Ghajar, I., Najafi, A., Torabi, S. A., Khamehchiyan, M., Boston, K. (2012a). An adaptive network-based fuzzy inference system for rock share estimation in forest road construction. - Croatian Journal of Forest Engineering 33(2): 313-328.

[29] Ghajar, I., Najafi, A., Torabi, S. A., Boston, K. (2012b). Rock share estimation in forest road excavation using the Ordinal Logistic Regression (OLR) and the Analytical Hierarchy Process (AHP). - Iranian Journal of Forest and Poplar Research 20(2): 313323. 
[30] Gu, T. Y., Ju, S. G., Han, F. (2009): A PSO algorithm with the improved diversity for feed forward neural networks. - Second International Symposium on Intelligent Information Technology and Security Informatics, January 23-25, Moscow, Russia, pp. $123-127$.

[31] Guan, B. T., Gertner, G. (1991): Modeling red pine tree survival with an artificial neural network. - Forest Science 37(5): 1429-1440.

[32] Güngör, İ., Kayacan, M. C., Korkmaz, M. (2004): Artificial neural networks use in the forecasting of industrial wood demand and comparison with different estimation methods. - YA/EM'2004 - Yöneylem Araştırmasi/Endüstri Mühendisliği - XXIV Ulusal Kongresi, 15-18 Haziran, Gaziantep, Adana.

[33] Haykin, S. (1994): Neural Networks: A Comprehensive Foundation. - Macmillan, New York.

[34] Haykin, S. (1999): Neural Networks and Learning Machines (Third Edition). - Pearson Prentice Hall Inc., Upper Saddle River, NJ.

[35] Hema, C. R., Paulraj, M. P., Nagarajan, R., Yaacob, S., Adom, A. H. (2008): Application of particle swarm optimization for EEG signal classification. - Biomedical Soft Computing and Human Sciences 13(1): 79-84.

[36] Heinrich, R. (1998): Recent development on environmentally friendly forest road construction and wood transport in mountainous forests. - Proceedings of the Seminar on Environmentally Sound Forest Roads and Wood Transport, Sinaia, Romania, 17-22 June 1996. FAO Publications. Rome, Italy.

[37] Hocking, R. R. (1976): The analysis and selection of variables in linear regression. Biometrics 32: 1-50.

[38] Huber, C., Stampfer, K. (2015): Efficiency of topping trees in cable yarding operations. Croat. J. for Eng. 36(2): 185-193.

[39] Karaman, A., Çalışkan, E. (2009): Affective factors weight estimation in tree felling time by artificial neural networks. - Expert Systems with Applications 36: 4491-4496.

[40] Kennedy, J., Eberhart, R. C. (1995): Particle swarm optimization. - Proc. IEEE Int'1 Conf. on Neural Networks, Vol. IV, pp. 1942-1948. IEEE Service Center, Piscataway, NJ.

[41] Krpan, A. P. B., Poršinsky, T., Marijan, S. (2001): Timber extraction technologies in Croatian mountainous selection forests. - Paper presented at the Joint FAO/ECE/ILO Committee on Forest Technology Workshop on New Trends in Wood Harvesting with Cable Systems for Sustainable Forest Management in the Mountains, 18-24 June 2001, Ossiach, Austria.

[42] Law, R., Au, N. (1999): A neural network model to forecast Japanese demand for travel to Hong Kong. - Tourism Management 20(10): 89-97.

[43] LeDoux, C. B., Huyler, N. K. (2000): Cost comparisons for three harvesting systems operating in northern hardwood stands. - USDA Forest Service, Northeastern Research Station, Research Paper NE-715, Delaware, USA.

[44] Leite, H. G., Marques da Silva, M. L., Binoti, D. H. B., Fardin, L., Takizawa, F. H. (2011): Estimation of inside-bark diameter and heartwood diameter for Tectona grandis Linn. Trees using artificial neural networks. - European Journal of Forest and Research 130: 263-269.

[45] Li, Y, Wang, L., Xing, Y. (2014): Extraction model of forest features based on mutation and bidirectional particle swarm optimization. - Computer Modelling \& New Technologies 18(12A): 215-220.

[46] Liping, Z., Huan-jun, Y., Shang-xu, H. (2005): Optimal choice of parameters for particle swarm optimization. - Journal of Zhejiang University Science 6(6): 528-534.

[47] Liu, L., Liu, W., Cartes, D. A. (2008): Particle swarm optimization based parameter identification applied to permanent magnet synchronous motors. - Engineering Applications of Artificial Intelligence 21: 1092-1100. 
[48] Naghdi, R., Ghajar, İ. (2012): Application of artificial neural network in the modeling of skidding time prediction. - Advanced Materials Research 403-408(2): 3538-3543.

[49] Olden, J. D., Jackson, D. A. (2008): Illuminating the "black box": a randomization approach for understanding variable contributions in artificial neural networks. - Ecol. Model. 154: 135-150.

[50] Özbeyaz, A. (2010): EMG ve EEG İşaretlerinin Sınıflandırılmasında EKK-DVM Hiper Parametrelerinin PSO’ ya Dayalı Seçimi. - Kahramanmaraş Sütçü İmam Üniversitesi Fen Bilimleri Enstitüsü, Kahramanmaraş.

[51] Özçelik, R., Diamantopoulou, M. J., Wiant, H. R., Brooks, J. R. (2008): Comparative study of Standard and modern methods for estimating tree bole volume of three species in Turkey. - Forest Products Journal 58(6): 73-81.

[52] Özçelik, R., Diamantopoulou, M. J., Wiant, H. V., Brooks, J. R. (2010): Estimating tree bole volume using artificial neural network models for four species in Turkey. - Journal of Environmental Management 91(3): 742-753.

[53] Özçelik, R., Diamantopoulou, M. J., Crecente-Campo, F., Eler, U. (2013): Estimating Crimean juniper tree height using nonlinear regression and artificial neural network models. - Forest Ecology and Management 306: 52-60.

[54] Öztemel, E. (2003): Yapay Sinir Ağları. - Papatya Yayıncılık, İstanbul.

[55] Özturk, T., Demir, M. (2007): Transporting of spruce timbers by cable system from selective forests of Artvin region. - Building and Environment 42: 1278-1282.

[56] Özturk, T., Şenturk, N. (2016): Productivity and costs of timber extraction by URUS MIII skyline yarder in Northeast Turkey. - Šumarski List 11-12(2016): 561-566.

[57] Öztürkcan, M. (2009): Regresyon Analizi. - Maltepe Üniversitesi Yayınları Sayı 3, No: 40.

[58] Rieger, G. (2001): Costs and performance of a Koller K300-yarder. - Paper presented at the Joint FAO/ECE/ILO Committee on Forest Technology Workshop on New Trends in Wood The ECOWOOD Project (Cable Systems). Harvesting with Cable Systems for Sustainable Forest Management in the Mountains, 18-24 June 2001, Ossiach, Austria.

[59] Pukkala, T. (2009): Population-based methods in the optimization of stand management. - Silva Fennica 43(2): 261-274.

[60] Proto, A. R., Zimbalatti, G. (2015): Firewood cable extraction in the southern Mediterranean area of Italy. - Forest Science and Technology 12(1): 16-23.

[61] Rumelhart, D. E., Hinton, G. E., Williams, R. J. (1986): Learning Internal Representations by Error Propagation. - In: Rumelhart, D. E., McClelland, J. L., Corporate PDP Research Group (eds.) Parallel Distributed Processing. MIT Press, Cambridge, MA, pp. 318-362.

[62] Russell, F, Mortimer, D. (2005): A Review of Small-Scale Harvesting Systems in Use Worldwide and their Potential Application in Irish Forestry. - COFORD, Dublin.

[63] Safi, Y., Bournoumi, A. (2013): Prediction of forest fires using artificial neural networks. - Applied Mathematical Sciences 7(6): 271-286.

[64] Shi, Y., Eberhart, R., C. (1998): Parameter Selection in Particle Swarm Optimization. Evolutionary Programming VII: Proc. EP 98. - Springer-Verlag, New York, pp. 591-600.

[65] Tamer, S., Karakuzu, C. (2006): Parçacık Sürüsü Optimizasyon Algoritması ve Benzetim Örnekleri. - Kocaeli Üniversitesi Mühendislik Fakültesi Elektronik ve Haberleşme Mühendisliği Bölümü, Kocaeli.

[66] Trzesniowski, A. (1998): Wood transport in steep terrain. - Proceedings of the Seminar on Environmentally Sound Forest Roads and Wood Transport, Sinaia, Romania, 17-22 June 1996. FAO Publications. Rome.

[67] Zhao, F., Ren, Z., Yu, D., Yang, Y. (2005): Application of An Improved Particle Swarm Optimization Algorithm for Neural Network Training. - 2005 International Conference on Neural Networks and Brain, 13-15 Oct. 2005. DOI: 10.1109/ICNNB.2005.1614955. 
[68] Zhang, C., Shao, H. (2000): An ANN's evolved by a new evolutionary system and its application. - Proceedings of the 39th IEEE Conference on Decision and Control, Sydney, Australia, pp. 3562-3563.

[69] Zimbalatti, G., Proto, A. R. (2009): Cable logging opportunities for firewood in Calabrian forests. - Biosystems Engineering 102: 63-68.

[70] Zimbalatti, G., Proto, A. R. (2010): Timber extraction with a cable crane in south Italy (Calabria). - FORMEC 2010, Forest Engineering: Meeting the Needs of the Society and the Environment, Padova, Italy. 